\title{
Effect of drying method on the adsorption isotherms and isosteric heat of passion fruit pulp powder
}

\author{
Efeito dos métodos de secagem nas isotermas e no calor isostérico de sorção da polpa de maracujá em pó
}

\author{
Maria Angélica Marques PEDRO ${ }^{1 \star}$, Javier TELIS-ROMEROํ, Vânia Regina Nicoletti TELIS ${ }^{1}$
}

\begin{abstract}
The sorption behavior of dry products is generally affected by the drying method. The sorption isotherms are useful to determine and compare thermodynamic properties of passion fruit pulp powder processed by different drying methods. The objective of this study is to analyze the effects of different drying methods on the sorption properties of passion fruit pulp powder. Passion fruit pulp powder was dehydrated using different dryers: vacuum, spray dryer, vibro-fluidized, and freeze dryer. The moisture equilibrium data of Passion Fruit Pulp (PFP) powders with $55 \%$ of maltodextrin (MD) were determined at $20,30,40$ and $50^{\circ} \mathrm{C}$. The behavior of the curves was type III, according to Brunauer's classification, and the GAB model was fitted to the experimental equilibrium data. The equilibrium moisture contents of the samples were little affected by temperature variation. The spray dryer provides a dry product with higher adsorption capacity than that of the other methods. The vibro-fluidized bed drying showed higher adsorption capacity than that of vacuum and freeze drying. The vacuum and freeze drying presented the same adsorption capacity. The isosteric heats of sorption were found to decrease with increasing moisture content. Considering the effect of drying methods, the highest isosteric heat of sorption was observed for powders produced by spray drying, whereas powders obtained by vacuum and freeze drying showed the lowest isosteric heats of sorption.

Keywords: water activity; maltodextrin; freeze drying; spray drying; vaccum drying; vibrofluidized bed.
\end{abstract}

\section{Resumo}

Os métodos de secagem geralmente influenciam o comportamento de sorção dos alimentos. As isotermas de sorção são úteis para determinar as propriedades termodinâmicas do produto em pó desidratado por diferentes métodos de secagem. O objetivo deste estudo foi analisar o efeito dos tipos de secadores nas propriedades de sorção da polpa de maracujá (PFP) com 55\% de maltodextrina (MD) em pó, obtida por vácuo, spray dryer, secador vibrofluidizado e liofilizador. As isotermas foram determinadas através do método estático gravimétrico na faixa de temperatura de 20 a $50^{\circ} \mathrm{C}$. As curvas apresentaram comportamento tipo III, de acordo com a classificação de Brunauer. O modelo de GAB se ajustou satisfatoriamente aos dados de umidade de equilíbrio. A temperatura não influenciou os teores de umidade de equilíbrio. O pó obtido pelo spray dryer apresentou uma capacidade de sorção maior em relação aos outros métodos testados. Já os pós obtidos por secagem a vácuo e pelo liofilizador apresentaram a menor capacidade de sorção. O calor isostérico de sorção diminuiu com o aumento do teor de umidade. Considerando os métodos de secagem, o pó produzido pelo spray dryer apresentou o maior valor do calor isostérico de sorção, enquanto aqueles produzidos por secagem a vácuo e pelo liofilizador apresentaram os menores valores do calor isostérico de sorção.

Palavras-chave: atividade de água; maltodextrina; liofilização; spray drying; secagem a vácuo; leito vibrofluidizado.

\section{Introduction}

Passion fruit is original from Tropical America and is grown widely in Brazil. Yellow passion fruit (Passiflora eduli) is the species with the greatest economical importance since its pulp, of yellow - orange coloration, provides good juice income. Passion fruit pulp is a good source of ascorbic acid (vitamin C) and carotenoids (vitamin A). It has a rich flavor and is pleasantly aromatic.

Brazil is the leading consumer of passion fruit. The country's production was 479.813 tons in 2005 (INSTITUTO..., 2007). It is considered that more than $60 \%$ of the Brazilian production of passion fruit is destined to the consumption in nature, and the remaining is destined to processing industries; and juice is the major product (TODA FRUTA, 2006).
Fruit products like passion fruit pulp present high water content, which makes them very susceptible to decomposition by microorganisms and chemical and enzymatic reactions. These products are extremely perishable and cannot be marketed or exported as fresh produce, generating post-harvest losses over 20 and 30\% (AGRIANUAL, 2003).

For the preservation of the fruits and of their original components, special attention has been given to the development of adequate drying techniques. In addition to aggregating commercial value to the fruits, drying reduces waste and postharvest losses and might allow their commercialization for extended periods of time with minor dependence on seasonal conditions (MARQUES; FERREIRA; FREIRE, 2007).

Recebido para publicação em 24/10/2008

Aceito para publicação em 8/7/2009 (003904)

${ }^{1}$ Departamento de Engenharia e Tecnologia de Alimentos, Universidade Estadual Paulista - UNESP, Rua Cristóvão Colombo, n. 2265, CEP 15054-000,

São José do Rio Preto - SP, Brazil, E-mail: mangelmp@ibilce.unesp.br

${ }^{*}$ A quem a correspondência deve ser enviada 
Powders obtained from pulp fruit represent an interesting market. This physical form provides a stable, natural, and easily dosable ingredient which may used to impart color and taste to food products (BHANDARI et al., 1993).

Ther are several types of dryers that may be used in drying of foods and they are chosen based on some characteristics of the process such as characteristics of the food, easiness of the processing, processed volume, conditions of the raw material, factors of economical origin and, mainly, the form that one wants to give to the final product. Due to the different characteristics of this material, no special drier is recommended for the paste drying process (FREIRE, 1992). According to Tsami, Krokida and Drouzas (1999), the final product characteristics such as water sorption, porosity, and color depend on the drying method used. Several changes can occur during drying of a food, including changes in solubility, rehydration, shrinkage, changes in shape, size, porosity, and density reduction, which can influence the adsorption capacity of the dried products.

Fluidized dryers are used to dry particulate solids, suspensions, pulps, and pastes, mainly due to the advantages of high heat and mass transfer rates produced between solids and hot air leading to low drying times. Fluidized drying of liquid feeds dispersed on the surface of inert particles also offers the advantages of producing powdered products in a dryer of much smaller volume than in a competitive spray-dryer resulting in lower investment and operating costs (KUDRA; MUJUMDAR, 1995).

Some of the food products suitable for fluidized bed dryer include beans, fruit granules, onion, flakes, and fruit juice powders (JAYARAMAN; GUPTA, 1995).

Spray dryers are used in drying of solutions, suspensions, emulsions, pulps, and pastes. When well driven, the dehydration by atomization of suspensions and nutritious pastes generates a product of larger nutritional value, stable, and also versatile in its use (MASTERS, 1991). Spray-dried powders usually have a small particle size, $10-100 \mu \mathrm{m}$, with poor handling and reconstitution properties (FUCHS et al., 2006). The residence time of particles in the spray dryer does not usually exceed 30 seconds. Microstructure analyses reported by Cano-Chauca et al. (2005) showed that the powders of mango juices obtained through spray drying using maltodextrin, gum arabic, and waxy starch presented characteristics of amorphous particles.

Vacuum drying has been successfully applied to many fruits and vegetables. Vacuum-dried products are characterized by their better quality retention in relation to hot air drying under atmospheric pressure.

Freeze-drying is a technique that results in high-quality dehydrated products due to the absence of liquid water and the low temperatures required in the process. The solid state of water during freeze-drying protects the primary structure and minimizes changes in the product shape, with minimal reduction of volume, providing a dry product with porous structure (RATTI, 2001). During the freeze-dehydration of fruit juices and pulp, products with a high degree of amorphous sugars are obtained. This state favors the high hygroscopicity and higher adsorption capacity (CARLOS; RESENDE; CAL-VIDAL, 2005).

Depending on the nature of food powder (crystalline or amorphous), the isotherms shape is different. Most food powders have complex structures, including potentially crystallisable solutes such as sugars, which show changes in crystallinity during the adsorption of water (MATHLOUTHI; ROGÉ, 2003). Carlos, Resende and Cal-Vidal (2005) confirm this behavior relating that the sorption characteristics were correlated with the degree of sugar crystallization.

The plot of equilibrium moisture content of materials versus water activity at a given temperature is referred as a sorption isotherm. Water sorption isotherms are useful thermodynamic tools for predicting the interaction between food components and water. Sorption isotherms can also be used to investigate structural features of a food product such as specific surface area, pore volume, pore size distribution, and crystallinity. Such data can be used for selecting appropriate storage conditions and packaging systems that optimize or maximize the retention of aroma, color, texture, nutrients, and biological stability, and they optimize the drying or rehydration conditions of a product (RIZVI, 1995).

The determination of the heat of sorption was the aim of several previous studies. Its knowledge is essential for the modeling of various food processes and food storage. In addition, it can be used to estimate the energy requirements of food drying and also provides important information about the state of water in food products (KAYA; KAHYAOGLU, 2005).

The adsorption isotherms of fruits and vegetables has been widely studied. Debnath, Hemavathy and Bhat (2002) reported the moisture sorption of onion powders obtained by freeze dryer and vacuum shelf drying. Costa, Medeiros and Mata (2003) determined adsorption isotherms for beetroot, pumpkin, and carrot, which were obtained in powder form using a spouted bed dryer. Alexandre, Figueirêdo and Queiroz (2007) showed the moisture adsorption isotherms of red Brazilian cherry powder produced using the foam-mat drying process. Gabas et al. (2007) and Martinelli, Gabas and Telis-Romero (2007) determined the adsorption isotherms of vacuum dried pineapple pulp powder and lemon pulp powder, respectively.

Since adsorption isotherms are generally affected by drying methods, it is also useful to determine and compare adsorption isotherms and thermodynamic properties of passion fruit pulp powder processed by different drying methods. The objective of this study is to analyze the effects of different drying methods on the sorption properties of passion fruit pulp powder.

\subsection{Mathematical development}

The Guggenheim, Anderson and de Boer (GAB) isotherm equation has been widely used to describe the sorption behavior of foods (MAROULIS et al., 1988; IGLESIAS; CHIRIFE, 1995). It is recommended to describe isotherms, and it has been extensively used for foodstuffs, especially for fruits (LOMAURO; BAKSHI; LABUZA, 1985a; GABAS; MENEGALLI; TELIS-ROMERO, 2000; TELIS et al., 2000). 
Having a reasonable small number of parameters (three), the GAB equation has been found to represent adequately the experimental data in the range of water activity of most practical interest in foods, i.e., $0.10 \pm 0.90$, and it is a relatively simple model with parameters that have a physical meaning.

It is mathematically expressed as (RIZVI, 1995) (Equation 1):

$X=\frac{(C-1) K a_{w} X_{m}}{1+(C-1) K a_{w}}+\frac{K a_{w} X_{m}}{1-K a_{w}}$

where: $\mathrm{a}_{\mathrm{w}}$ is the water activity, $\mathrm{Xm}$ is the moisture content (dry basis) corresponding to an adsorbed monolayer (BET), and C and $\mathrm{K}$ are the $\mathrm{GAB}$ model constants related to the temperature effect.

The isosteric heat of sorption $\left(\mathrm{q}_{\mathrm{st}}\right)$ is defined as the difference between the total heat of sorption $\left(\mathrm{Q}_{\mathrm{st}}\right.$ and the heat of vaporization of water. It can be determined from the following equation, which is derived from the Clausius-Clapeyron equation (RIZVI, 1995) (Equation 2):

$\left.\frac{\partial \ln \left(a_{w}\right)}{\partial(1 / T)}\right|_{X}=-\frac{Q_{s t}-\lambda}{R}=-\frac{q_{s t}}{R}$

where: $\mathrm{q}_{\mathrm{st}}$ is the isosteric heat of sorption $\left(\mathrm{kJ} \cdot \mathrm{mol}^{-1}\right), \mathrm{Q}_{\mathrm{st}}$ is the total heat of sorption $\left(\mathrm{kJ} \cdot \mathrm{mol}^{-1}\right), \lambda$ is the heat of condensation of pure water $\left(\mathrm{kJ} \cdot \mathrm{mol}^{-1}\right), \mathrm{R}$ is the universal gas constant (8.314 J.mol-1 $\mathrm{K}$ ), and $\mathrm{T}$ is the absolute temperature $(\mathrm{K})$.

The isosteric heat of sorption is a differential molar quantity derived from the temperature dependence of the isotherms. This approach assumes that the isosteric heat is invariant with temperature, and the application of this method requires the measurement of sorption isotherms at two or more temperature values (McLAUGHLIN; MAGEE, 1998).

\section{Materials and methods}

\subsection{Raw material}

Samples of passion fruit (Passiflora edulisf. flavicarpa) with moisture content of $88 \%$ (wet basis) were obtained at the local market (São José do Rio Preto - SP, Brazil) and stored at $7{ }^{\circ} \mathrm{C}$ prior to use. A batch of passion fruit pulp was prepared in a pilot plant finisher and sieved through a $1.6 \mathrm{~mm}$-mesh.

An aqueous solution with 50\% solids (mass basis) was prepared by dispersing commercial maltodextrin MOR-REX ${ }^{\oplus}$ 1910 (Corn Products Brazil) in distilled water at $40^{\circ} \mathrm{C}$ using a mechanical stirrer. This solution was added to the passion fruit pulp and the mass ratio between maltodextrin solution and pulp was $1,22 \mathrm{~kg}$ maltodextrin. $1 \mathrm{~kg}^{-1}$ soluble solids $(55 \%$ maltodextrin).

\subsection{Drying methods}

\section{Vibro-fluidized bed dryer}

The drying chamber of the vibro-fluidized bed consisted of a vertical glass cylinder of $165 \mathrm{~mm}$ in diameter and $704 \mathrm{~mm}$ high. The chamber was suspended by a spindle and connected to a DC motor that drove the eccentric wheel, which imparted vertical sinusoidal vibration to the drying chamber. The frequency and amplitude of vibration could be set from 15 to $40 \mathrm{~Hz}$ and from 1 to $3 \mathrm{~mm}$, respectively. In the present study, the frequency and amplitude of vibration used were $25 \mathrm{~Hz}$ and $2 \mathrm{~mm}$, respectively. The air temperature used was $70^{\circ} \mathrm{C}$, and air speed was $3.8 \mathrm{~m} /$ second (CABRAL et al., 2007). The inert particles were supported by a grid having $9.4 \%$ free crosssectional area, which was formed of $2.5 \mathrm{~mm}$ holes punched in a $2 \mathrm{~mm}$ stainless steel sheet forming a $60^{\circ}$ rotated triangular staggered array configuration. The paste material to be dried was fed continuously to the drying chamber, at constant rate, by a peristaltic pump and dispersed by a central single stream nozzle with $5 \mathrm{~mm}$ of diameter. The dry powder separated from inert particles by attrition was carried out of the drying chamber along with the exhausted air and collected in a cyclone.

\section{Spray dryer}

The spray dryer (model SD 5.0, Labmaq do Brazil LTDA) operates concurrently and has a spray nozzle with an orifice of $2 \mathrm{~mm}$ in diameter. The inlet air temperature was about $140{ }^{\circ} \mathrm{C}$ and the outlet air temperature was about $102^{\circ} \mathrm{C}$. The liquid feed to the dryer was between 1 and 1,5 L/hour. The drying air flow was about $12 \mathrm{~m}^{3}$ /hour (MARTINELLI, 2008). The experiments were performed under constant process conditions. The dry powder separated from the inert particles by attrition was carried out of the drying chamber along with the exhausted air and collected in a cyclone.

The material obtained was placed into plastic bags, which were stored in a desiccator containing silica gel until posterior utilization.

\section{Freeze dryer}

The passion fruit pulp was put into three stainless steel trays and frozen before drying in a freezer (LIOTOP, FV500) at $-40{ }^{\circ} \mathrm{C}$. Freeze-drying tests were performed in a freezedryer model L101 (LIOBRAS, Brazil) with vacuum chamber total pressure and temperature equal to $500 \mu \mathrm{Hg}$ and $-45^{\circ} \mathrm{C}$, respectively, for 48 hours.

The freeze-dryer is constituted of a transparent acrylic cylindrical drying chamber of $35 \mathrm{~cm}$ covered with a stainless steel top with eight silicone faucets to fit the glass bottles with round bottom (vacuum relief system). A silica adapter and a stainless steel pipe connect the bottles to the faucets establishing the linking between faucets and bottle. Inside of the drying chamber, there is a shelf that serves as the support to four stainless steel trays. The samples can be placed on the trays or in the glass bottles. The vacuum is produced through a vacuum pump that is connected to the freeze-dryer through a hose. At the end of the.process, the dried product was removed and ground in a hammer mill.

\section{Vacuum chamber dryer}

The samples of pulp were dried on a stainless steel tray inserted into a vacuum chamber (MARCONI, MA 030) at $60{ }^{\circ} \mathrm{C}$ for 48 hours (GABAS et al., 2007). The dried product was ground in a hammer mill. 


\subsection{Sorption isotherms}

Equilibrium moisture contents of the pulp powder under different conditions of water activity were determined by the static gravimetric method (JOWITT et al., 1983) at 20, 30, 40 and $50^{\circ} \mathrm{C}$. Ten saturated salt solutions $\left(\mathrm{NaOH}, \mathrm{LiCl}, \mathrm{KC}_{2} \mathrm{H}_{3} \mathrm{O}_{2}\right.$, $\mathrm{MgCl}_{2}, \mathrm{~K}_{2} \mathrm{CO}_{3}, \mathrm{MgNO}_{3}, \mathrm{NaNO}_{2}, \mathrm{NaCl}, \mathrm{KCl}$ e $\mathrm{BaCl}_{2}$ ) were prepared corresponding to a range of water activities from 0.06 to 0.90 . Each solution was transferred to separated jars in a sufficient quantity to occupy a space of about $1.5 \mathrm{~cm}$ depth at the jar bottom. Triplicate samples of around $1 \mathrm{~g}$ of passion fruit powder were weighed in small plastic receptacles and placed on tripods in the jars, which were then tightly closed and placed in a temperature-controlled chamber. The required equilibration time was 4 to 5 weeks, based on the change in the sample weight expressed on a dry basis, which did not exceed $0.1 \%$ (0.001 g. $\mathrm{g}^{-1}$ dry solids). The equilibrium moisture content was determined by the gravimetric method, in a vacuum oven at $60{ }^{\circ} \mathrm{C}$ for 48 hours (ASSOCIATION..., 1990).

\section{Results}

The experimental moisture sorption data determined at $20,30,40$, and $50{ }^{\circ} \mathrm{C}$ for the passion fruit pulp powder with $55 \%$ of maltodextrin obtained using different dryers are shown in Table 1 . The moisture content for each level of water activity represents the mean value of three replicates. The sorption isotherms demonstrate an increase in equilibrium moisture content with increasing water activity, under constant temperature (Figure 1).

The obtained isotherms are of type III, according to Braunauer's classification, for most of the examined temperatures and all drying methods. The typical effect of the temperature during equilibration time on the isotherms is shown for the powders produced in the spray dryer in Figure 1.

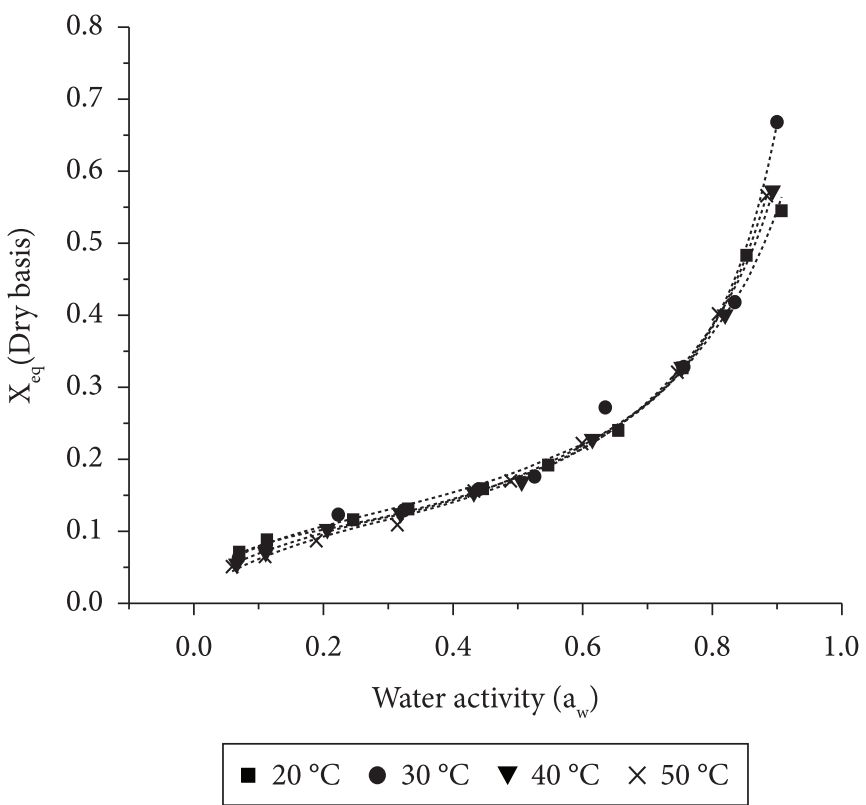

Figure 1. Influence of temperature on sorption isotherms of passion fruit pulp powder with $55 \%$ of maltodextrin 10 DE dried in spray dryer.
This shape of the curves is characteristic of foods with high sugar contents, which sorbs small amounts of water at low water activity and large amounts of water at high relative humidity. The explanation for the nature of the isotherms may be that at low water activities, physical sorption on strongly active sites occurs since water can be sorbed only to surface - OH sites of crystalline sugar (GOULA et al., 2008).

The effect of the equilibration temperature on the sorption isotherms is of great importance given that foods are exposed to a range of temperatures during storage and processing, and

Table 1. Experimental equilibrium moisture contents (dry basis) for passion fruit pulp powders with $55 \%$ of maltodextrin $10 \mathrm{DE}$.

\begin{tabular}{|c|c|c|c|c|c|}
\hline & & $\begin{array}{c}\text { Vacuum } \\
\text { dryer }\end{array}$ & $\begin{array}{l}\text { Vibro-fluidized } \\
\text { bed }\end{array}$ & $\begin{array}{l}\text { Spray } \\
\text { dryer }\end{array}$ & $\begin{array}{c}\text { Freeze } \\
\text { dryer }\end{array}$ \\
\hline $\begin{array}{c}\text { Temperature } \\
\left({ }^{\circ} \mathrm{C}\right)\end{array}$ & $\mathrm{a}_{\mathrm{w}}$ & $\mathrm{X}_{\mathrm{eq}}$ & $\mathrm{X}_{\mathrm{eq}}$ & $X_{e q}$ & $X_{e q}$ \\
\hline \multirow{9}{*}{$20^{\circ} \mathrm{C}$} & 0.0700 & 0.0450 & 0.0620 & 0.0710 & 0.0460 \\
\hline & 0.1130 & 0.0520 & 0.0770 & 0.0880 & 0.0510 \\
\hline & 0.2460 & 0.0760 & 0.1010 & 0.1160 & 0.0750 \\
\hline & 0.3310 & 0.0850 & 0.1150 & 0.1310 & 0.0830 \\
\hline & 0.4460 & 0.1030 & 0.1390 & 0.1590 & 0.1030 \\
\hline & 0.5470 & 0.1190 & 0.1680 & 0.1920 & 0.1190 \\
\hline & 0.6550 & 0.1600 & 0.2100 & 0.2400 & 0.1610 \\
\hline & 0.7540 & 0.2070 & 0.2860 & 0.3270 & 0.2060 \\
\hline & 0.8530 & 0.2870 & 0.4210 & 0.4830 & 0.2860 \\
\hline \multirow{11}{*}{$30^{\circ} \mathrm{C}$} & 0.9070 & 0.3810 & 0.4810 & 0.5450 & 0.3800 \\
\hline & 0.0690 & 0.0390 & 0.0610 & 0.0630 & 0.0380 \\
\hline & 0.1120 & 0.0470 & 0.0780 & 0.0760 & 0.0460 \\
\hline & 0.2230 & 0.0760 & 0.1030 & 0.1230 & 0.0780 \\
\hline & 0.3240 & 0.0790 & 0.1210 & 0.1290 & 0.0780 \\
\hline & 0.4390 & 0.0970 & 0.1480 & 0.1580 & 0.0960 \\
\hline & 0.5260 & 0.1080 & 0.1750 & 0.1760 & 0.1050 \\
\hline & 0.6350 & 0.1680 & 0.2190 & 0.2720 & 0.1720 \\
\hline & 0.7560 & 0.2030 & 0.3160 & 0.3280 & 0.2000 \\
\hline & 0.8350 & 0.2580 & 0.4290 & 0.4180 & 0.2520 \\
\hline & 0.9000 & 0.3700 & 0.4700 & 0.6680 & 0.3750 \\
\hline \multirow{9}{*}{$40^{\circ} \mathrm{C}$} & 0.0660 & 0.0340 & 0.0500 & 0.0550 & 0.0350 \\
\hline & 0.1110 & 0.0440 & 0.0670 & 0.0710 & 0.0430 \\
\hline & 0.2060 & 0.0630 & 0.0880 & 0.1030 & 0.0620 \\
\hline & 0.3190 & 0.0770 & 0.1090 & 0.1250 & 0.0740 \\
\hline & 0.4320 & 0.0950 & 0.1340 & 0.1540 & 0.0950 \\
\hline & 0.5060 & 0.1050 & 0.1550 & 0.1690 & 0.1050 \\
\hline & 0.6150 & 0.1400 & 0.1930 & 0.2280 & 0.1410 \\
\hline & 0.7530 & 0.2020 & 0.2920 & 0.3280 & 0.2010 \\
\hline & 0.8200 & 0.2480 & 0.3810 & 0.4010 & 0.2470 \\
\hline \multirow{11}{*}{$50^{\circ} \mathrm{C}$} & 0.8930 & 0.3540 & 0.4630 & 0.5730 & 0.3520 \\
\hline & 0.0590 & 0.0320 & 0.0440 & 0.0510 & 0.0330 \\
\hline & 0.1100 & 0.0400 & 0.0660 & 0.0650 & 0.0390 \\
\hline & 0.1890 & 0.0530 & 0.0860 & 0.0870 & 0.0520 \\
\hline & 0.3140 & 0.0670 & 0.1110 & 0.1090 & 0.0640 \\
\hline & 0.4320 & 0.0970 & 0.1400 & 0.1560 & 0.0980 \\
\hline & 0.4890 & 0.1050 & 0.1570 & 0.1700 & 0.1040 \\
\hline & 0.5990 & 0.1370 & 0.1960 & 0.2220 & 0.1380 \\
\hline & 0.7460 & 0.1980 & 0.3050 & 0.3210 & 0.1970 \\
\hline & 0.8090 & 0.2480 & 0.3730 & 0.4020 & 0.2470 \\
\hline & 0.8840 & 0.3490 & 0.4510 & 0.5660 & 0.3470 \\
\hline
\end{tabular}


water activity changes with temperature for the same moisture content (GOULA et al., 2008). The equilibrium moisture content tends to decrease with increasing temperature at constant water activity. The extent of the decrease depends on the nature or constitution of the food (RIZVI, 1995). In the case of passion fruit pulp powder, this behavior was not so pronounced, independently of the dryer used to obtain the powder. Goula et al. (2008) reported that for spray dried tomato pulp the temperature effect was not dependent on water activity and this might be due to the fact that tomato powder contains high levels of protein and insoluble solids. Gabas et al. (2007) compared isotherms of vacuum dried pineapple pulp powder and Martinelli, Gabas and Telis-Romero (2007) compared isotherms of vacuum dried lemon pulp powder, both found values between 20 and $50{ }^{\circ} \mathrm{C}$, and also detected only a small dependence of sorption data on temperature.

A marked intersection of the isotherms and the inverse temperature effect were not observed for passion fruit pulp powders, but there was a tendency for this 'crossing-over' at higher water activities. This result is in accordance with those obtained by Gabas et al. (2007) and Martinelli, Gabas and Telis-Romero (2007). Some studies have reported this inversion in the temperature effect at water activities above 0.7 for products with high sugar content such as fruits (TELISROMERO et al., 2005; TSAMI et al., 1990), which can be explained by an increase in sugar solubility in water caused by increasing temperature.

The results of the fitting procedure of the GAB model to the experimental data of equilibrium moisture content at different water activities are presented in Table 2 , which shows the values of the fitting parameters calculated by non-linear regression. In addition to $\mathrm{R}^{2}$, the criterion used to evaluate the goodness of the model fitting was the mean relative percentage deviation modulus, $\mathrm{M}_{\mathrm{e}}$, defined as (Equation 3):

$M_{e}=\frac{100}{N} \sum_{i=1}^{N} \frac{\left|m_{i}-m_{p i}\right|}{m_{i}}$

where: $m_{i}$ is the experimental value, $m_{p i}$ is the predicted value, and $\mathrm{N}$ is the number of experimental data.

The mean relative percentage deviation modulus $\left(\mathrm{M}_{\mathrm{e}}\right)$ has been widely adopted throughout the literature with a modulus value below 10 acknowledged as an indicative of a good fit for practical purposes (LOMAURO; BAKSHI; LABUZA, 1985b). The analysis of Table 2 shows that the GAB equation can be considered satisfactory for fitting the sorption data of passion fruit pulp powder.

The value of the monolayer moisture content $\left(\mathrm{X}_{\mathrm{m}}\right)$ is of particular interest since it indicates the amount of water that is strongly adsorbed to specific sites at the food surface, and it is considered as the optimum value to assure food stability. Below it, the rates of deteriorative reactions, except for those of oxidation for unsaturated fats, are minimized (GOULA et al., 2008). Estimated values for $X_{m}$ for the passion fruit pulp powders were found to be lower than the values available for other fruits, which vary between 10 and 15\% (dry basis), as reported by Kiranoudis et al. (1993). The values of $\mathrm{X}_{\mathrm{m}}$ obtained by vacuum and freeze drying were smaller than those for spray dried and vibro-fluidized dried passion fruit pulp. The monolayer values for passion fruit pulp powder obtained by different dryers showed no clear temperature dependence.

The parameter $\mathrm{C}$ showed distinct trends for different drying methods. For vacuum, vibro-fluidized, and freeze dried materials, the $\mathrm{C}$ values decreased as temperature increased. For spray dried products, values $\mathrm{C}$ showed no clear temperature dependence. According to Goula et al. (2008), the values for $\mathrm{K}$ were smaller than 1 as dictated by the GAB equation. The parameter $\mathrm{K}$ was practically unaffected by the drying method.

The effect of dryer types on the sorption isotherms is shown in Figure 2, for $20^{\circ} \mathrm{C}$, and in Figure 3, for $50{ }^{\circ} \mathrm{C}$. For both temperatures, the effect of the drying method on the isotherms behavior was the same.

The spray dryer provides a dry product with higher adsorption capacity than that of the other methods. The vibrofluidized bed drying showed higher adsorption capacity than that of vacuum and freeze drying.

Freeze and vacuum dried products showed the same adsorption capacity. These drying methods present some similarities. Both are based on drying in the absence of air providing products with very porous structure. Nevertheless, the adsorption capacity might not be directly related with porosity since in order to obtain powders, the products resulting from freeze and vacuum drying processes were ground. This factor could also be responsible for the similar

Table 2. Estimated GAB parameters at different temperatures for powders obtained by different drying methods.

\begin{tabular}{|c|c|c|c|c|}
\hline \multirow[t]{2}{*}{ Parameter } & \multicolumn{4}{|c|}{ Temperature } \\
\hline & $20^{\circ} \mathrm{C}$ & $30^{\circ} \mathrm{C}$ & $40^{\circ} \mathrm{C}$ & $50^{\circ} \mathrm{C}$ \\
\hline \multicolumn{5}{|c|}{ Vacuum drying } \\
\hline $\mathrm{C}$ & 27.1935 & 21.0243 & 16.6632 & 11.9695 \\
\hline $\mathrm{K}$ & 0.9182 & 0.9194 & 0.9262 & 0.9304 \\
\hline $\mathrm{X}_{\mathrm{m}}$ & 0.0638 & 0.0636 & 0.0617 & 0.0630 \\
\hline $\mathrm{R}^{2}$ & 0.9992 & 0.9925 & 0.9994 & 0.9989 \\
\hline$M_{e}$ & 1.9624 & 5.3058 & 1.7012 & 3.6473 \\
\hline \multicolumn{5}{|c|}{ Vibro-fluidized bed drying } \\
\hline $\mathrm{C}$ & 20.9855 & 12.7802 & 9.3710 & 9.3719 \\
\hline $\mathrm{K}$ & 0.8969 & 0.8653 & 0.8747 & 0.8747 \\
\hline $\mathrm{X}_{\mathrm{m}}$ & 0.0935 & 0.1111 & 0.1080 & 0.1080 \\
\hline $\mathrm{R}^{2}$ & 0.9932 & 0.9857 & 0.9938 & 0.9945 \\
\hline $\mathrm{M}_{\mathrm{e}}$ & 4.0934 & 6.4948 & 7.6547 & 5.6328 \\
\hline \multicolumn{5}{|c|}{ Spray drying } \\
\hline $\mathrm{C}$ & 20.4724 & 30.7748 & 16.6068 & 16.9043 \\
\hline $\mathrm{K}$ & 0.8943 & 0.9515 & 0.9256 & 0.9253 \\
\hline $\mathrm{X}_{\mathrm{m}}$ & 0.1077 & 0.0944 & 0.1003 & 0.0877 \\
\hline $\mathrm{R}^{2}$ & 0.9919 & 0.9889 & 0.9992 & 0.9991 \\
\hline $\mathrm{M}_{\mathrm{e}}$ & 4.3918 & 6.5771 & 1.9793 & 10.3296 \\
\hline \multicolumn{5}{|c|}{ Freeze drying } \\
\hline $\mathrm{C}$ & 26.9378 & 22.5826 & 16.1033 & 11.4567 \\
\hline $\mathrm{K}$ & 0.9182 & 0.9253 & 0.9253 & 0.9291 \\
\hline $\mathrm{X}_{\mathrm{m}}$ & 0.0636 & 0.0620 & 0.0617 & 0.0631 \\
\hline $\mathrm{R}^{2}$ & 0.9991 & 0.9872 & 0.9992 & 0.9980 \\
\hline $\mathrm{M}_{\mathrm{e}}$ & 2.4754 & 1.7939 & 5.5302 & 34.0684 \\
\hline
\end{tabular}


adsorption capacity observed between the powders obtained by these two drying methods.

Tonon, Brabet and Hubinger (2008) related that the materials produced by spray drying showed spherical particles. The spherical particles provide a larger surface area than that of irregular shape particles (for the same particle volume) produced by vibro-fluidized bed drying. Probably, this is the reason for the highest adsorption capacity of spray dried materials.

The dependence of the isosteric heat of sorption on moisture content for passion fruit pulp powder with $55 \%$ of maltodextrin is shown in Figure 4. The results illustrate a progressive increase of the sorption heat in relation to the decreasing moisture content. Al-Muhtaseb, McMimm and Magee (2004) stated that this may be possibly due to the fact that at the initial stages of sorption (low moisture content) there are highly active polar sites available on the surface of the food material, which are covered with water molecules to form a monomolecular layer. This results in stronger water-solid interactions. Goula et al. (2008) related that the main water-adsorbing constituents in foods are various polymers (proteins, starch, cellulose, hemicellulose, etc.) and sugars. The different polar groups of the polymers provide energetically different sites for sorption. As the water content increases, the covering of less active adsorption sites and the formation of multilayer is manifested by the decrease in the heat of sorption (PÉREZ-ALONSO et al., 2006).

In almost the whole range of moisture content the $\mathrm{q}_{\mathrm{st}}$, the values corresponding to powders produced by spray drying were the highest. This suggests that the spray dried product has more surface polar sites than those of the products obtained by the other drying methods. The elevated heat values of sorption of water under low moisture contents are an indication of strong water-food component interactions in the fruit.

Values of $\mathrm{q}_{\text {st }}$ were correlated by Equation 4 (TSAMI et al., 1990) resulting in the constants $\mathrm{q}_{0}$ and $X_{0}$, as well as in the

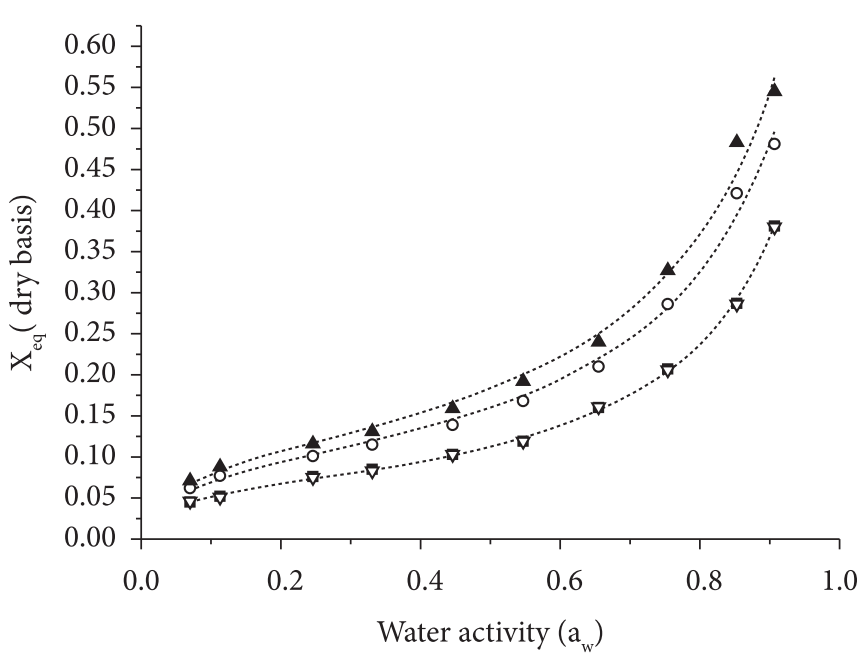

- Vacuum $\circ$ Vibro-fluidized $\boldsymbol{\Delta}$ Spray dryer $\nabla$ Freeze dryer

Figure 2. Influence of different drying methods on the sorption isotherms of passion fruit pulp powder determined at $20^{\circ} \mathrm{C}$. values of the determination coefficient $\left(\mathrm{R}^{2}\right)$, which are shown in Table 3. In general, the values of the determination coefficient $\left(\mathrm{R}^{2}\right)$ were satisfactory.

$q_{s t}=q_{o} * \exp \left(\frac{X}{X_{o}}\right)$

In Equation $4, \mathrm{q}_{0}$ is the isosteric heat of sorption (constant) of the first water molecular layer and $\mathrm{X}_{0}$ (constant) is the initial moisture content of a food material.

The calculated values of $\mathrm{q}_{0}$ were higher for vacuum dried than for vibro-fluidized bed dried, spray dried,and freeze dried materials. It is possible that this behavior is a result of mathematical compensation among parameters.

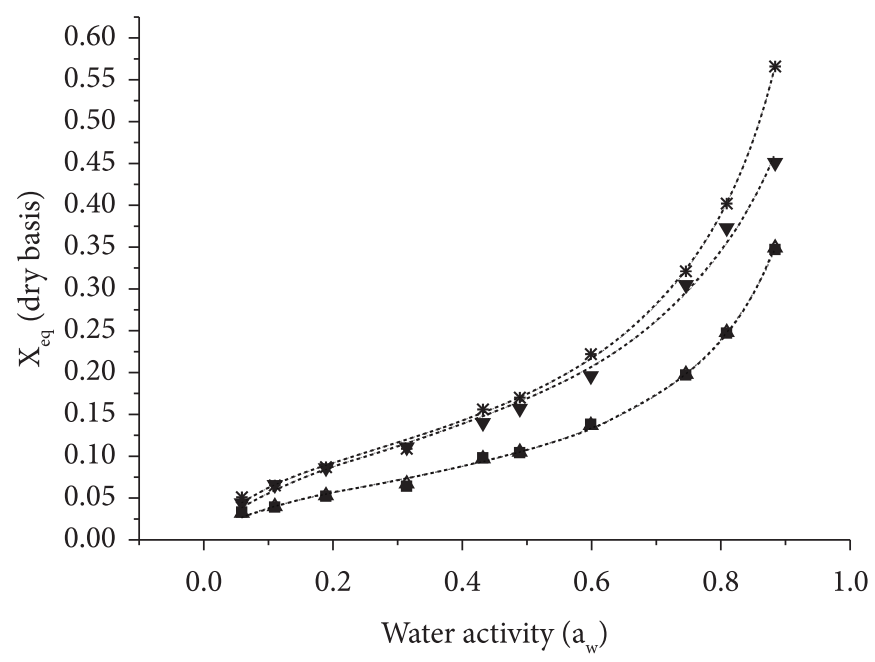

$\Delta$ Vacuum $\boldsymbol{\nabla}$ Vibro-fluidized $*$ Spray dryer - Freeze dryer

Figure 3. Influence of different drying methods on the sorption isotherms of passion fruit pulp powder determined at $50{ }^{\circ} \mathrm{C}$.

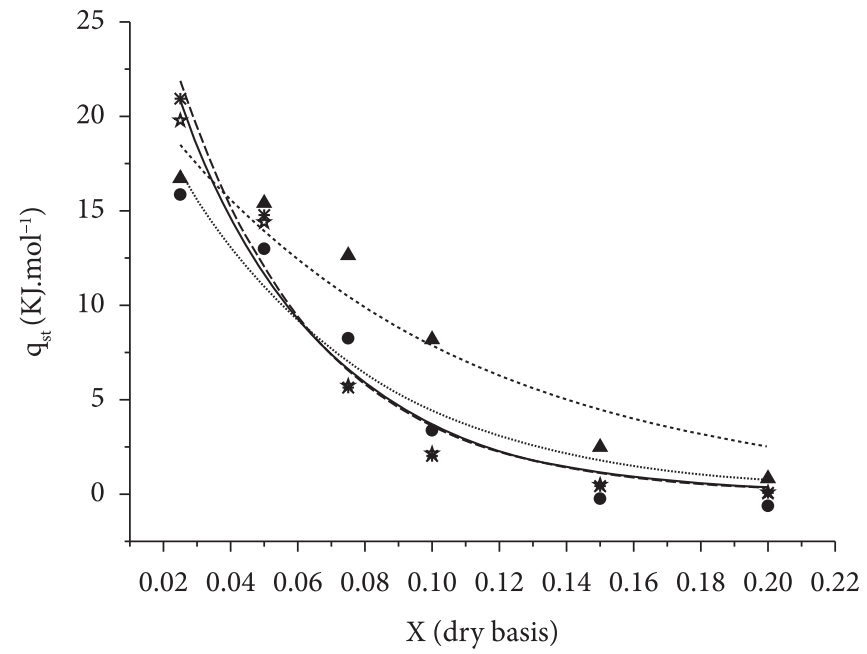

« Vacuum • Vibro-fluidized $\Delta$ Spray dryer * Freeze dryer

Figure 4. Influence of drying methods on the sorption isosteric heat of passion fruit pulp powders. 
Table 3. Estimated parameters of the empirical Eq. 3 for samples dried by different methods.

\begin{tabular}{lccc}
\hline Drying method & $\mathrm{q}_{0}\left(\mathrm{~kJ} \cdot \mathrm{mol}^{-1}\right)$ & $\mathrm{X}_{0}$ (dry basis $)$ & $\mathrm{R}^{2}$ \\
\hline Vacuum dryer & 36.9857 & 0.0432 & 0.9640 \\
Vibro-fluidized bed & 26.8367 & 0.0556 & 0.9383 \\
Spray dryer & 24.5913 & 0.0877 & 0.9238 \\
Freeze dryer & 39.9473 & 0.0415 & 0.9663 \\
\hline
\end{tabular}

\section{Conclusions}

The adsorption isotherms for the samples of passion fruit pulp powders with $55 \%$ of maltodextrin obtained by vacuum dryer, vibro-fluidized bed dryer, spray, and freeze dryer presented type III behavior, according to Brunauer's classification.

The drying method significantly affects the sorption capacity of the dry product. The spray dryer provides a dry product with higher adsorption capacity than that of the other studied methods. The vibro-fluidized bed drying showed higher adsorption capacity than that of vacuum and freeze drying that presented the same adsorption capacity.

The isosteric heat of sorption increased with the decrease in moisture content. In almost the whole range of moisture content, the values of the isosteric heat of sorption corresponding to powders produced by spray drying were the highest.

\section{Acknowledgements}

The authors would like to thank the financial support received from CAPES and for Corn Products Brazil.

\section{References}

AGRIANUAL: anuário da agricultura brasileira. São Paulo: FNP, 2003.

ALEXANDRE, H. V.; FIGUEIRÊDO, R. M. F.; QUEIROZ, A. J. M. Isotermas de adsorção de umidade da pitanga em pó. Revista de Biologia e Ciências da Terra, v. 7, n.1, p. 11-20, 2007.

AL-MUHTASEB, A. H.; McMINN, W. A. M.; MAGEE, T. R. A. Water sorption isotherms of starch powders. Part 2: thermodynamic characteristics. Journal of Food Engineering, v. 62, n. 2, p. 135-142, 2004.

ASSOCIATION OF OFFICIAL ANALYTICAL CHEMISTS - AOAC. Official methods of analysis. 15th ed. Arlington: AOAC, 1990.

BHANDARI, B. R. et al. Spray drying of concentrated fruit juices. Dry Technology, v. 11, n. 5, p. 1081-1092, 1993.

CABRAL, R. A. F. et al. Effect of apparent viscosity on fluidized bed drying process parameters of guava pulp. Journal of Food Engineering, v. 80, p. 1096-1106, 2007.

CANO-CHAUCA, M. et al. Effect of the carriers on the microstructure of mango powder obtained by spray drying and its functional characterization. Innovative Food Science and Emerging Technologies, v. 6, n. 4, p. 420-428, 2005.

CARLOS, L. A.; RESENDE, J. D.; CAL-VIDAL, J. Redução da higroscopicidade de pós liofilizados pela indução da cristalização em soluções-modelo de açúcares constituintes de frutas. Brazilian Journal of Food Technology, v. 8, n. 2, p. 163-173, 2005.

COSTA, J. M. C.; MEDEIROS, M. F. D.; MATA, A. L. M. Isotermas de adsorção de pós de beterraba (Beta vulgaris L.), abóbora (Cucurbita moschata) e cenoura (Daucus carota) obtidos pelo processo de secagem em leito de jorro: estudo comparativo. Revista Ciência Agronômica, v. 34, n. 1, p. 5-9, 2003.

DEBNATH, S.; HEMAVATHY, J.; BHAT, K. K. Moisture sorption studies on onion powder. Food Chemistry, v. 78, n. 4, p. 479-482, 2002.

FREIRE, J. T. Paste drying in spouted bed. In: FREIRE, J. T.; SARTORI, D. J. M. (Eds.). Special topics in drying. São Carlos: EDUFSCar, 1992. chap. 2, p. 42-85.

FUCHS, C. et al. Encapsulation of oil in powder using spray drying and fluidized bed agglomeration. Journal of Food Engineering, v. 75, n. 1, p. 27-35, 2006.

GABAS, A. L. et al. Effect of maltodextrin and arabic gum in water vapor sorption thermodynamic properties of vacuum dried pineapple pulp powder. Journal of Food Engineering, v. 82, n. 2, p. 246-252, 2007.

GABAS, A. L.; MENEGALLI, F. C.; TELIS-ROMERO, J. Water sorption enthalpy-entropy compensation based on isotherms of plum skin and pulp. Journal of Food Science, v. 5, n. 4, p. 680-684, 2000.

GOULA, A. M. et al. Water sorption isotherms and glass transition temperature of spray dried tomato pulp Journal of Food Engeneering, v. 85, n. 1, p. 73-83, 2008.

IGLESIAS, H. A.; CHIRIFE, J. An alternative to the Guggenheim, Anderson and De Boer model for the mathematical description of moisture sorption isotherms of foods. Food Research International, v. 28, n. 3 , p. $317-321,1995$.

INSTITUTO BRASILEIRO DE FRUTAS - IBRAF. Produção brasileira de frutas frescas por estado. 2005. Available from: <http://www. ibraf.org.br>. Access in: 7 Sept. 2006.

JAYARAMAN, K. S.; GUPTA, D. K. Drying of fruits and vegetables: handbook of industrial drying. New York: Marcel Dekker, 1995.

JOWITT, R. et al. Physical properties of foods. London: Applied Science, 1983.

KAYA, S; KAHYAOGLU, T. Thermodynamic properties and sorption equilibrium of pestil (grape leather). Journal of Food Engineering, v. 71, n. 2 , p. $200-207,2005$.

KIRANOUDIS, C. T. et al. Equilibrium moisture content and heat of desorption of some vegetables. Journal of Food Engineering, v. 20, n. 6, p. 55-74, 1993.

KUDRA, T.; MUJUMDAR, A. S. Special drying techniques and novel dryers. In: MUJUMDAR, A. S. (Ed.). Handbook of industrial drying. New York: Marcel Dekker, 1995. part II, chap. 20, p. 1087-1150.

LOMAURO, C. J.; BAKSHI, A. S.; LABUZA, T. P. Evaluation of food moisture isotherm equations. Part I: Fruit, vegetable and meat products. Lebensmittel-Wissenschaft Technologie, v. 18, n.2, p. 111-117, 1985a.

LOMAURO, C. J.; BAKSHI, A. S.; LABUZA, T. P. Moisture transfer properties of dry and semi moist foods. Journal of Food Science, v. 50, n. 5, p. 397-400, 1985b.

MAROULIS, Z. B. et al. Application of the GAB model to the moisture sorption isotherms for dried fruits. Journal of Food Engineering, v. 7, n. 1, p. 63-78, 1998.

MARQUES, L. G.; FERREIRA, M. C.; FREIRE, J. T. Freeze-drying of acerola (Malpighia glabra L.). Chemical Engineering and Processing, v. 46, n. 5, p. 451-457, 2007.

MARTINELLI, L. Construção e desenvolvimento de um secador de leito pulso-fluidizado para secagem de pastas e polpas. 2008. 148 f. Dissertação (Mestrado em Engenharia e Ciência de 
Alimentos)-Instituto de Biociências, Letras e Ciências Exatas, Universidade Estadual Paulista, São José do Rio Preto, 2008.

MARTINELLI, L.; GABAS, A. L.; TELIS-ROMERO, J. Thermodynamic and quality properties of lemon juice powder as affected by maltodextrin and arabic gum. Dry Technology, v. 25, n.10, p. 2035-2045, 2007.

MASTERS, K. Spray drying handbook. 5th ed. New York: Longman Scientific \& Technical, 1991.

MATHLOUTHI, M.; ROGÉ, B. Water vapour sorption isotherms and the caking of food powders. Food Chemistry, v. 82, n. 1, p. 61-71, 2003.

MCLAUGHLIN, C. P.; MAGEE, T. R. A. The determination of sorption isotherm and the isosteric heats of sorption for potatoes. Journal of Food Engineering, v. 35, n. 3, p. 267-280, 1998.

RATTI, C. Hot air and freeze drying of high-value foods: a review. Journal of Food Engineering, v. 49, n. 4, p. 311-319, 2001.

PÉREZ-ALONSO, C. et al. Thermodynamic analysis of the sorption isotherms of pure and blended carbohydrate polymers. Journal of Food Engineering, v. 77, n. 4, p. 753-760, 2006.
RIZVI, S. S. H. Rheological properties of fluid foods. In: RAO, M. A.; RIZVI, S. S. H. (Eds.). Engineering properties of foods. 2nd ed. New York: Academic Press, 1995.

TELIS, V. R. N. et al. Water sorption thermodynamic properties applied to persimmon skin and pulp. Thermochimica Acta, v. 343, n. 1-2, p. 49-56, 2000.

TELIS-ROMERO, J. et al. Enthalpy-entropy compensation based on isotherms of ango. Ciência e Tecnologia de Alimentos, v. 25, n. 2, p. 297-303, 2005.

TODA FRUTA. Informações econômicas sobre o maracujá. Available from: <http://www.todafruta.com.br>. Access in: 14 Feb. 2006.

TONON, R. V.; BRABET, C.; HUBINGER, M. D. Influence of process conditions on the physicochemical properties of açai (Euterpe oleraceae Mart.) powder produced by spray drying. Journal of Food Engineering, v. 88, n. 3, p. 411-418, 2008.

TSAMI, E. et al. Heat of sorption of water in dried fruits. International Journal of Food Science and Technology, v. 25, n. 3, p. 350-359, 1990.

TSAMI, E.; KROKIDA, M. K; DROUZAS, A. E. Effect of drying method on the sorption characteristics model fruit powders. Journal of Food Engineering, v. 38, n. 4, p. 381-302, 1999. 